Article

\title{
Properties of Carbon-supported Precious Metals Catalysts under Reductive Treatment and Their Influence in the Hydrodechlorination of Dichloromethane
}

\author{
Alejandra Arevalo-Bastante, Maria Martin-Martinez *®e, M. Ariadna Álvarez-Montero ${ }^{\circledR}$, \\ Juan J. Rodriguez and Luisa M. Gómez-Sainero \\ Departamento de Ingeniería Química, Facultad de Ciencias, Universidad Autónoma de Madrid, Cantoblanco, \\ 28049 Madrid, Spain; alejandrarevalo.b@gmail.com (A.A.-B.); ariadna.alvarez@uam.es (M.A.Á.-M.); \\ juanjo.rodriguez@uam.es (J.J.R.); luisa.gomez@uam.es (L.M.G.-S.) \\ * Correspondence: maria.martin.martinez@uam.es; Tel.: +34-91-497-5527
}

Received: 27 November 2018; Accepted: 14 December 2018; Published: 18 December 2018

\begin{abstract}
This study analyzes the effect of the reduction temperature on the properties of $\mathrm{Rh}, \mathrm{Pt}$ and Pd catalysts supported on activated carbon and their performance in the hydrodechlorination (HDC) of dichloromethane (DCM). The reduction temperature plays an important role in the oxidation state, size and dispersion of the metallic phase. $\mathrm{Pd}$ is more prone to sintering, followed by $\mathrm{Pt}$, while $\mathrm{Rh}$ is more resistant. The ratio of zero-valent to electro-deficient metal increases with the reduction temperature, with that effect being more remarkable for $\mathrm{Pd}$ and $\mathrm{Pt}$. The higher resistance to sintering of Rh and the higher stability of electro-deficient species under thermal reductive treatment can be attributed to a stronger interaction with surface oxygen functionalities. Dechlorination activity and a TOF increase with reduction temperature $\left(250-450{ }^{\circ} \mathrm{C}\right)$ occurred in the case of $\mathrm{Pt} / \mathrm{C}$ catalyst, while a great decrease of both was observed for $\mathrm{Pd} / \mathrm{C}$, and no significant effect was found for $\mathrm{Rh} / \mathrm{C}$. $\mathrm{Pt}^{0}$ represents the main active species for HDC reaction in $\mathrm{Pt} / \mathrm{C}$. Therefore, increasing the relative amount of these species increased the TOF value, compensating for the loss of dispersion. In contrast, $\mathrm{Pd}^{\mathrm{n}+}$ appears as the main active species in $\mathrm{Pd} / \mathrm{C}$ and their relatively decreasing occurrence together with the significant decrease of metallic area reduces the HDC activity. Rh/C catalyst suffered only small changes in dispersion and metal oxidation state with the reduction temperature and thus this variable barely affected its HDC activity.
\end{abstract}

Keywords: precious metals; reduction temperature; hydrodechlorination; XPS; dispersion; turnover frequency

\section{Introduction}

Catalysis plays a crucial role on the path of building a more sustainable industrial chemistry and diminishes the impact of the industrial processes in the environment. Synthesizing novel, more stable, active and selective catalysts, or effectively improving the existing ones, is a fundamental task.

Chloromethanes are chlorinated volatile organic compounds with serious environmental impact, due to their carcinogenic and highly toxic character, in addition to the production of photochemical smog, the depletion of ozone and global warming [1-4]. Regardless of their noxious effects, some of these compounds, like dichloromethane (DCM) and chloroform (TCM), remain irreplaceable in some of their applications because of their singular chemical and physical properties (high stability, volatility and solvent capacity, and low flammability). Hence, they are still extensively used in industry, and large amounts are discharged into the environment through gaseous and liquid streams. 
Catalytic hydrodechlorination (HDC) is a promising technology for the treatment of these contaminated streams. It allows the conversion of organochlorinated species like chloromethanes into harmless chlorine-free compounds under relatively mild conditions. It is effective within a wide range of concentrations, and thus presents environmental and economic advantages over other techniques [5-7]. Furthermore, it may be applied 'in situ', in combination with other physical separation processes like adsorption, for the end-of-pipe treatment of residual streams generated in different industries [8].

A wide diversity of catalysts has been used in the HDC of several chlorocarbons and chlorofluorocarbons. Those based on noble metals supported by a porous material like alumina, silica or activated carbon, are the most common $[6,9,10]$. Among the publications related to the HDC with activated carbon-based catalysts, metals like $\mathrm{Pd}, \mathrm{Pt}, \mathrm{Rh}, \mathrm{Ru}$ or Ni are the most frequent active phases found, with $\mathrm{Pd}$ being by far the most preferred one, due to its high capacity for the hydrogenolysis of C-Cl bonds [11-13]. This metal, as well as Pt and Rh, have demonstrated high activity and dechlorination capacity [12,14-23]. Several authors have reported relationships between the catalyst performance and different properties, like metal particles structure, catalyst porosity or surface chemistry. However, there is no consensus on the trends observed, being highly dependent on the reactants and the catalytic systems used. Several authors relate better HDC performances to small metal particle sizes [24-29]. On the contrary, higher turnover frequency (TOF) values were obtained when increasing metal particle size in other HDC studies [30-33]. The optimum particle size seems to depend on the particular reaction. Diaz et al. [25] associated Pd and Rh particles of sizes within 3-4 nm with higher activities in the HDC of 4-chlorophenol. The same reaction was studied by Baeza et al. [28] using size-controlled Rh nanoparticles within the 1.9-4.9 nm range. They reported the highest activity with the smaller nanoparticles, in agreement with the optimum size found by Ren et al. [27], who claimed that small and uniform Rh particles of $1.7 \mathrm{~nm}$ induced higher activity. Dantas Ramos et al. [30], found a decrease of TOF with increasing dispersion in the HDC of CFC-12 and TCM, and Bedia et al. [31] observed a TOF decrease in the HDC of DCM when decreasing metal particle size (from 2.26 to $1.86 \mathrm{~nm}$ ). The metal oxidation state also affects the catalyst performance. A higher proportion of zero-valent $\mathrm{Rh}^{0}$ has been associated with higher activity and selectivity towards cyclohexanol in the HDC of 4-chlorophenol, while a higher proportion of electro-deficient $\mathrm{Rh}^{\mathrm{n}+}$ induced a higher selectivity to phenol [28]. Cobo et al. [34] also found that a higher $\mathrm{Rh}^{0} / \mathrm{Rh}^{\mathrm{n}+}$ ratio favors the HDC of trichloroethane with catalysts supported on $\mathrm{CeO}_{2}$. But with reduced graphene oxide, $\mathrm{Rh}^{\mathrm{n}+}$ better interacts with the surface functional groups of the support, favoring the HDC [27]. In previous studies of our group [12,19,35], four different activated carbon-supported catalysts $(\mathrm{Ru} / \mathrm{C}, \mathrm{Rh} / \mathrm{C}, \mathrm{Pd} / \mathrm{C}$ and $\mathrm{Pt} / \mathrm{C})$ were compared for the gas phase HDC of chloromethanes, finding attractive results in terms of catalytic activity. All the catalysts were considerably active, showing $\mathrm{Rh} / \mathrm{C}, \mathrm{Pd} / \mathrm{C}$ and $\mathrm{Pt} / \mathrm{C}$ have the best dechlorination capacity, although with significant differences in terms of activity, selectivity and stability. $\mathrm{Pt} / \mathrm{C}$ led mainly to methane formation, while $\mathrm{Rh} / \mathrm{C}$ and $\mathrm{Pd} / \mathrm{C}$ were more selective to higher hydrocarbons ( $\mathrm{C} 2$ and $\mathrm{C} 3$ ). Besides, with Rh/C higher amounts of olefins were obtained $[12,14,16,19]$. On the other hand, while $\mathrm{Pt} / \mathrm{C}$ showed itself to be highly stable (demonstrated in long-term experiments up to 26 days on stream), the other two metallic catalysts experienced a progressive loss of activity $[16,19,36]$. This exceptional stability was also found for a catalyst supported on sulfated zirconia with a bimetallic Pd-Pt active phase during the HDC of dichloromethane (DCM) [37]. In all of the cases, the characterization of the catalysts revealed important differences in their physico-chemical properties. In particular, the oxidation state and particle size of the metallic active phase were revealed as determinant properties on the selectivity, activity and stability of the catalysts $[19,36,37]$. Higher proportions of electro-deficient metallic $\left(\mathrm{M}^{\mathrm{n}+}\right)$ species combined with lower metal dispersions favored the selectivity to olefins and alkanes other than methane. On the contrary, higher proportions of zero-valent species $\left(\mathrm{M}^{0}\right)$ and high metal dispersions promoted better stability. Understanding how these properties are conferred to the catalysts and their optimization to achieve a better performance in the HDC reaction is of crucial interest. These properties can be, to some extent, modulated varying the reduction conditions during the preparation of the catalysts, which may be used as an easy strategy for improving the catalytic activity or tuning the reaction selectivity. 
Hence, in the current study, the effect of the reduction temperature (Tred) of Rh/C, Pd/C and $\mathrm{Pt} / \mathrm{C}$ catalysts on their properties and behavior in the HDC of cloromethanes is analyzed, using DCM as the target compound.

\section{Results and Discussion}

\subsection{Characterization of the Catalysts}

The reducibility of the metallic phase in each catalyst was determined in a previous work by temperature-programmed reduction (TPR) [14]. In that study, it was shown to be a single reduction peak for Pd and Pt corresponding to the reduction of $\mathrm{M}^{2+}$ to $\mathrm{M}^{0}$, centered at 233 and $244{ }^{\circ} \mathrm{C}$, respectively. $\mathrm{Rh} / \mathrm{C}$ displayed three peaks, centered at 86,125 and $222^{\circ} \mathrm{C}$. From these results, $250{ }^{\circ} \mathrm{C}$ was selected as the minimum reduction temperature to be tested and the range of $250-450{ }^{\circ} \mathrm{C}$ was covered.

The metal content of the non-reduced and reduced catalysts, as determined by mass spectrometry with inductive coupling plasma (ICP-MS), was always close to the nominal value $(1.0 \% \mathrm{w} / \mathrm{w})$ and no significant loss of metal occurred at any of the reduction temperatures. The reduction of the catalyst even at the highest temperature did not alter significantly the amount of metallic phase.

As can be seen in Table 1, all the catalysts showed an important BET surface area $\left(\mathrm{S}_{\mathrm{BET}}\right)$, above $1200 \mathrm{~m}^{2} \mathrm{~g}^{-1}$, and no considerable differences were observed after reduction at any of the temperatures tested.

Table 1. BET surface area $\left(\mathrm{m}^{2} \cdot \mathrm{g}^{-1}\right)$ of the catalysts reduced at different temperatures.

\begin{tabular}{cccc}
\hline Tred $\left({ }^{\circ} \mathbf{C}\right)$ & $\mathbf{P t} / \mathbf{C}$ & $\mathbf{P d} / \mathbf{C}$ & $\mathbf{R h} / \mathbf{C}$ \\
\hline 250 & 1236 & 1200 & 1210 \\
350 & 1266 & 1246 & 1253 \\
450 & 1247 & 1251 & 1209 \\
\hline
\end{tabular}

The most significant effects associated with the reduction temperature were observed in the dispersion and the oxidation state of the metal on the surface of the catalyst (Table 2). The metal dispersion values, as determined by $\mathrm{CO}$ chemisorption, prove that $\mathrm{Rh}$ was well dispersed with only some slight dispersion decrease at the highest reduction temperature. $\mathrm{Pt} / \mathrm{C}$ and $\mathrm{Pd} / \mathrm{C}$ yielded significantly lower dispersion values, although were still quite good at the lowest reduction temperatures. Increasing reduction temperature caused a gradual dispersion decrease, more marked in the case of $\mathrm{Pd} / \mathrm{C}$. The lowest reduction temperature led in the three cases to the highest dispersion. This temperature allows the reduction of most of the metal particles, as confirmed by the TPR profiles [14].

Table 2 also presents the relative distribution of the surface metallic species (zero-valent and electro-deficient) at the different reduction temperatures tested. These results were achieved from the deconvolution of the $\mathrm{Pt} 4 \mathrm{f}, \mathrm{Pd} 3 \mathrm{~d}$, and Rh $3 \mathrm{~d}$ X-ray photoelectron spectroscopy (XPS) profiles (see Figures S1-S3 in the supplementary material). Both metallic species exist in all of the reduction temperatures tested, even at the highest one, although, as expected, the relative occurrence of $\mathrm{M}^{0}$ increased with the reduction temperature. However, this effect is of a significantly different intensity depending on the catalyst, being much more noticeable in the case of $\mathrm{Pt} / \mathrm{C}$ and $\mathrm{Pd} / \mathrm{C}$, and showing lower significance for $\mathrm{Rh} / \mathrm{C}$. Moreover, in the latter, the electro-deficient species always remains the most abundant. This can be attributed to a different interaction of the metal precursor with the support, as pointed out by the TPR results, where three peaks of $\mathrm{H}_{2}$ consumption were observed with $\mathrm{Rh} / \mathrm{C}$, in comparison with the single peak of $\mathrm{Pd} / \mathrm{C}$ and $\mathrm{Pt} / \mathrm{C}$. The higher amount of $\mathrm{M}^{\mathrm{n}+}$ species points to a solid interaction of rhodium particles with the activated carbon, allowing a higher stability of $\mathrm{M}^{\mathrm{n}+}$ species even at the highest reduction temperature. This would also explain the very low change of dispersion upon reduction. It is noteworthy that in $\mathrm{Pt} / \mathrm{C}$, most of the metal appears as zero-valent species, even at the lowest reduction temperature, in good agreement with other carbon-supported platinum catalysts reported in previous works, where platinum was reduced at 250 and $300{ }^{\circ} \mathrm{C}[14,16,19,38]$. 
Table 2. Dispersion values, surface metal $\left(\mathrm{M}_{\mathrm{XPS}}\right)$ and oxygen $\left(\mathrm{O}_{\mathrm{XPS}}\right)$ atomic concentrations, relative distribution of the surface metallic species $\left(\mathrm{M}^{0} / \mathrm{M}^{\mathrm{n}+}\right)$ and $\mathrm{O}_{\mathrm{COOH}} / \mathrm{O}_{\text {total }}$ ratios of the catalysts reduced at different temperatures.

\begin{tabular}{ccccccc}
\hline Catalyst & Tred & Dispersion & $\mathbf{M}_{\mathbf{X P S}}$ & $\mathbf{M}^{\mathbf{0}} \mathbf{M}^{\mathbf{n}+}$ & $\mathbf{O}_{\mathbf{X P S}}$ & $\mathbf{O}_{\mathbf{C O O H}} / \mathbf{O}_{\text {total }}$ \\
\hline \multirow{3}{*}{$\mathrm{Pt} / \mathrm{C}$} & 250 & 28 & 0.06 & 2.8 & 5.05 & 0.20 \\
& 300 & 26 & 0.07 & 2.9 & 6.70 & 0.21 \\
& 350 & 23 & 0.05 & 3.2 & 4.11 & 0.20 \\
& 400 & 19 & 0.06 & 5.1 & 4.11 & 0.22 \\
& 450 & 12 & 0.07 & 7.5 & 4.35 & 0.23 \\
\hline $\mathrm{Pd} / \mathrm{C}$ & 250 & 23 & 0.08 & 1.0 & 5.65 & 0.28 \\
& 300 & 22 & 0.09 & 1.3 & 4.96 & 0.29 \\
& 350 & 16 & 0.13 & 1.5 & 4.96 & 0.27 \\
& 400 & 13 & 0.09 & 2.4 & 4.89 & 0.34 \\
$\mathrm{Rh} / \mathrm{C}$ & 450 & 10 & 0.08 & 2.4 & 3.93 & 0.36 \\
& 350 & 51 & 1.5 & 0.7 & 6.86 & 0.12 \\
& 300 & 48 & 1.5 & 0.8 & 6.64 & 0.11 \\
& 400 & 49 & 1.4 & 0.8 & 6.86 & 0.12 \\
& 450 & 48 & 1.4 & 0.9 & 7.00 & 0.12 \\
\hline
\end{tabular}

The values of oxygen atomic concentrations on the surface of the catalysts are also included in Table 2. A higher amount of surface oxygen can be observed for $\mathrm{Rh} / \mathrm{C}$, which also remains more stable under reduction, while some significant decrease is observed in $\mathrm{Pd} / \mathrm{C}$ and $\mathrm{Pt} / \mathrm{C}$ at increasing reduction temperatures. O 1s orbital was also deconvoluted according to literature [39] as shown in Figure 1. The following groups were assessed: $\mathrm{C}=\mathrm{O}(531.1 \mathrm{eV}), \mathrm{C}-\mathrm{OH}(532.3 \mathrm{eV}), \mathrm{C}-\mathrm{O}-\mathrm{C}(533.3 \mathrm{eV}), \mathrm{C}-\mathrm{OOH}$ (534.2 eV) and $\mathrm{H}_{2} \mathrm{O}(535.9 \mathrm{eV}$ ) [39]. All the XPS profiles are included in Figures S4-S6 of supplementary material. The $\mathrm{O}_{\mathrm{COOH}} / \mathrm{O}_{\text {total }}$ ratio (Table 2) represents the proportion of carboxylic groups (C-OOH) with respect to the total concentration of surface oxygenated groups. It provides information of the surface acidity of the catalysts. The amount of surface groups of the catalysts and their acid-base character may have some important effects on the changes occurring during the $\mathrm{H}_{2}$ treatment. A higher amount of surface oxygen groups favors the interaction between metal and support [40,41], avoiding the sintering of particles. On the other hand, the low ratios of carboxylic groups (Table 2) indicate that all the catalysts have a basic character on the surface, suggesting the prominent role of basic groups in the formation of electro-deficient species. Furthermore, $\mathrm{Rh} / \mathrm{C}$ catalyst, which show the higher distribution of electro-deficient species, presents the higher amount of surface oxygen $\left(\mathrm{O}_{\mathrm{XPS}}\right)$ and the lowest $\mathrm{O}_{\mathrm{COOH}} / \mathrm{O}_{\text {total }}$ ratio, which does not vary with reduction temperature, suggesting a stronger interaction of $\mathrm{Rh}$ precursor with the support that results in a higher resistance of Rh particles to sintering, in accordance with the results obtained. In contrast, $\mathrm{Pt} / \mathrm{C}$ and $\mathrm{Pd} / \mathrm{C}$ show a lower amount of surface groups and a lower basic character, observing some variations with reduction temperature.

Some representative transmission electron microscopy (TEM) images and the corresponding metal particle size distributions of the catalysts reduced at $450{ }^{\circ} \mathrm{C}$, are shown in Figure 2 . The images reveal smaller metallic particles in $\mathrm{Rh} / \mathrm{C}$, showing a mean particle diameter of $1.9 \mathrm{~nm}$ and a narrower distribution. These results agrees with the dispersion values calculated from $\mathrm{CO}$ chemisorption included in Table 2. The mean metal particle size obtained for Pd/C $(6.0 \mathrm{~nm})$ after reduction at $450{ }^{\circ} \mathrm{C}$ was significantly higher than the one previously reported [38] after reduction at $250{ }^{\circ} \mathrm{C}(1.9 \mathrm{~nm})$, consistent with the loss of dispersion at increasing reduction temperatures (Table 2). Other authors have reported similar behavior in carbon-supported Pd catalysts [30]. With regard to $\mathrm{Pt} / \mathrm{C}$, the mean particle size after reduction at the highest temperature is $2.5 \mathrm{~nm}$, also higher than the 1.6 and $1.7 \mathrm{~nm}$ previously obtained for the catalyst reduced at $250{ }^{\circ} \mathrm{C}[23,38]$. Therefore, it can be concluded that sintering of metallic particles takes place during reduction at increasing temperatures, although to different extents, in the cases of Pt and Pd catalysts. 


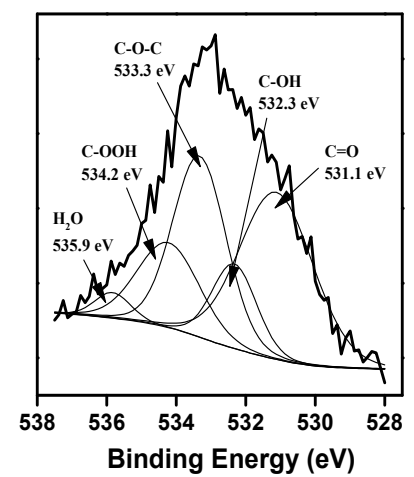

Figure 1. Deconvolution of $\mathrm{O} 1 \mathrm{~s}$ spectra of $\mathrm{Pd} / \mathrm{C}$ catalyst reduced at $300^{\circ} \mathrm{C}$.
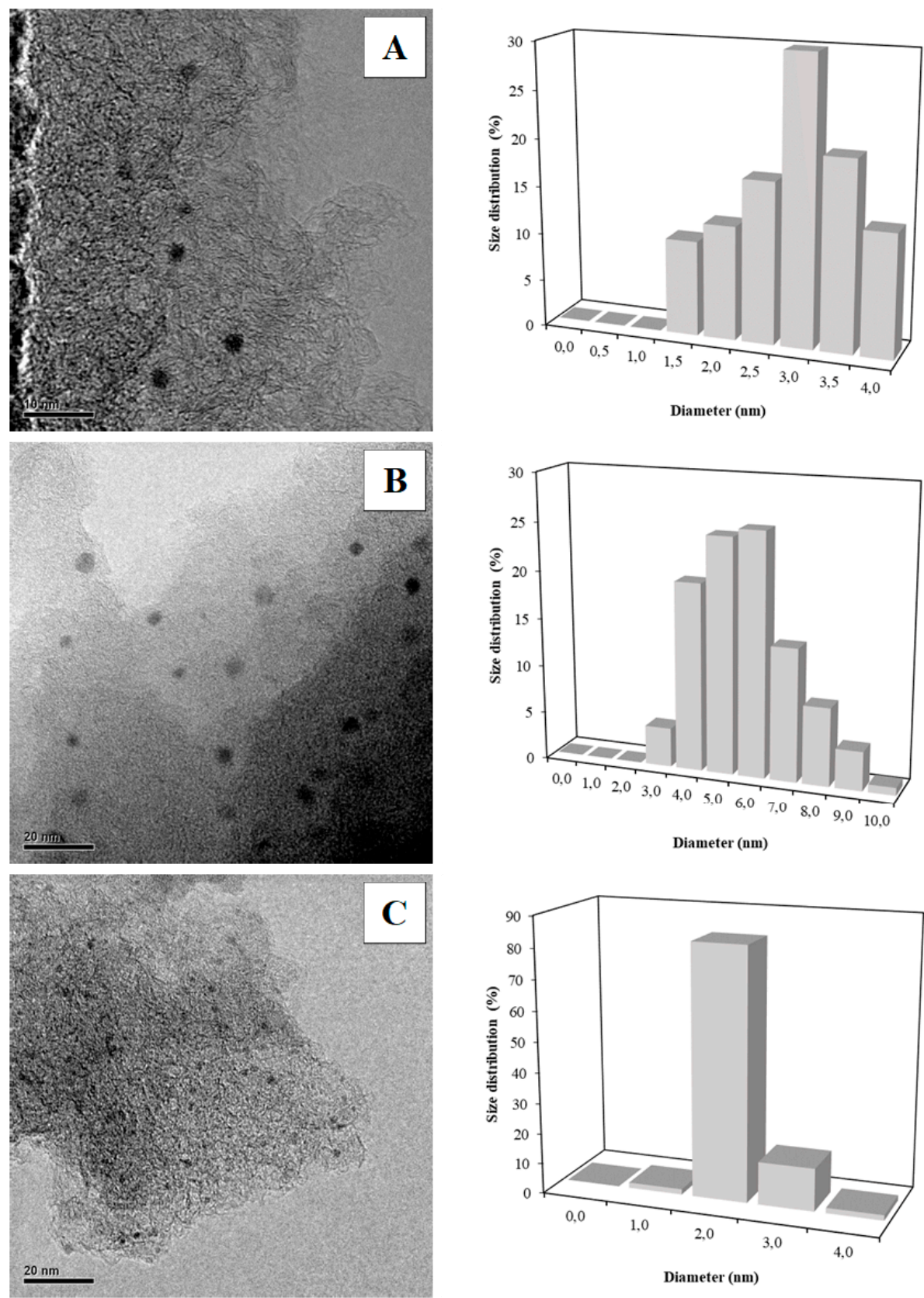

Figure 2. TEM images (left) and metal particles size distributions (right) of catalysts reduced at $450{ }^{\circ} \mathrm{C}$ : (A) $\mathrm{Pt} / \mathrm{C}$; (B) Pd/C; (C) Rh/C. 
The X-ray diffraction (XRD) profiles of the catalysts reduced at different temperatures (Figure 3) show the characteristic peaks of the carbon support (dash lines) at $2 \theta$ values nearly $26^{\circ}$ (planes 002), $43^{\circ}$ (planes 100, 101 and 102, indistinguishable) and $80^{\circ}$ (planes 110) [42-44]. As can be seen, XRD profiles were similar regardless of the reduction temperature. The peaks associated with zero-valent metal, which should be centered at $39.9^{\circ}, 40.1^{\circ}$ and $41.1^{\circ}$, respectively $[12,14,44,45]$, were not observed in these patterns, supporting the small particle size of these metals for all the reduction temperatures investigated, as observed by TEM (Figure 2). In addition, in all cases, one peak appeared at $35^{\circ}\left(^{*}\right.$ ) at the lowest reduction temperature $\left(250^{\circ} \mathrm{C}\right)$, associated with the presence of metal chlorides $\left(\mathrm{PtCl}_{2}\right.$, $\mathrm{PdCl}_{2}$, and $\mathrm{RhCl}_{3}$ ) from the precursors used in the preparation of the catalysts. Furthermore, these compounds seem to disappear at higher reduction temperatures, since this favors the desorption of $\mathrm{Cl}$ from the surface of the activated carbon.

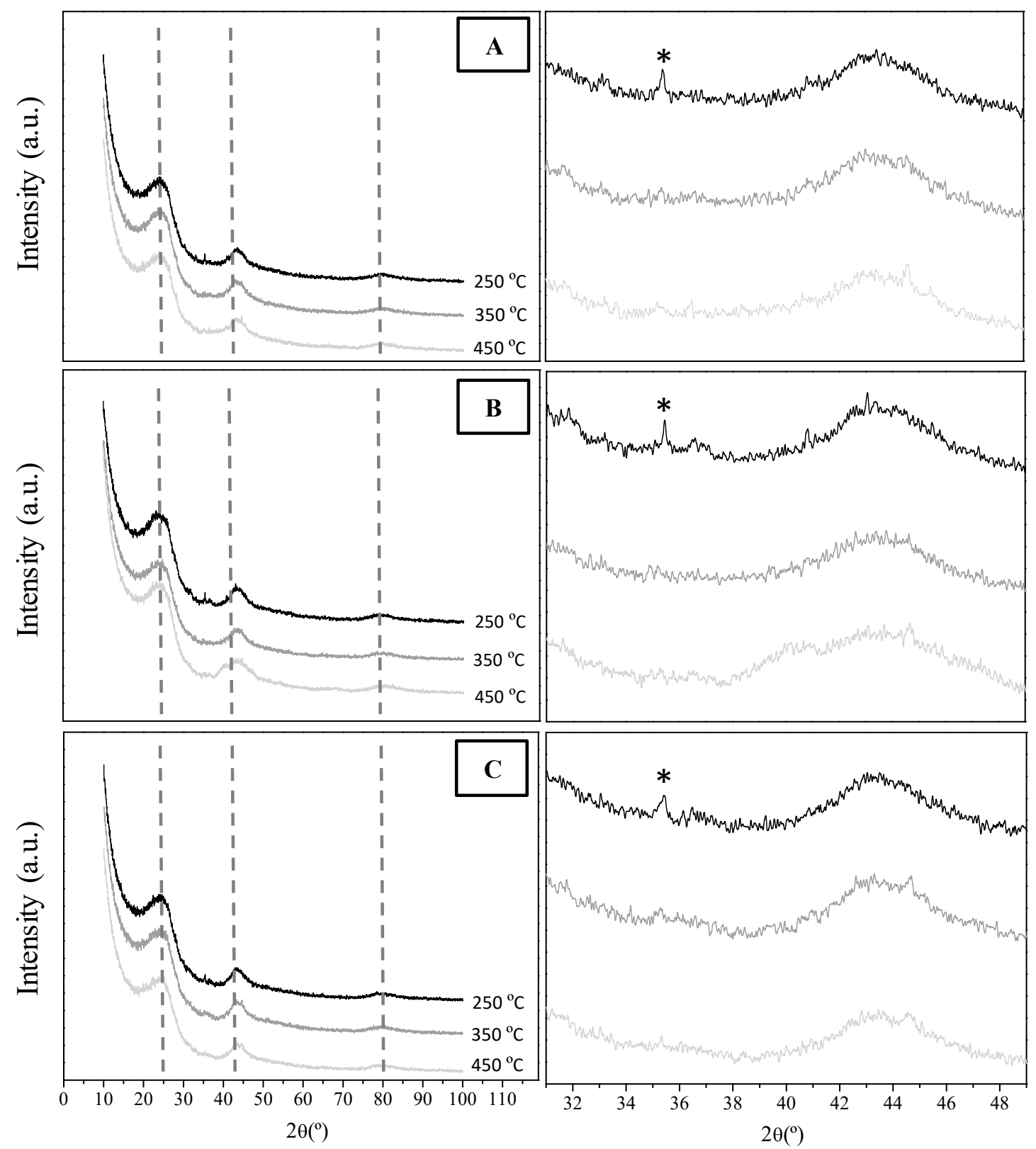

Figure 3. XRD diffractograms of: (A) Pt/C; (B) Pd/C; (C) Rh/C. 


\subsection{Hydrodechlorination Results}

Figure 4 shows the results obtained in the HDC of DCM with the Pt/C catalyst reduced at different temperatures, within the range of $150-250{ }^{\circ} \mathrm{C}$ reaction temperature. As can be seen, increasing the reduction temperature improves moderately overall dechlorination, in spite of the decrease of $\mathrm{Pt}$ dispersion. Therefore, some other effect must be compensating for the loss of dispersion. As shown in Table 2, the relative amount of zero-valent $\mathrm{Pt}\left(\mathrm{Pt}^{0}\right)$ rises significantly with the reduction temperature. These $\mathrm{Pt}^{0}$ species have proven to be the most active on the HDC of DCM with $\mathrm{Pt} / \mathrm{C}$ catalyst in previous studies $[16,23]$. Figure 4 includes the evolution of TOF with the reduction temperature of the catalyst. The TOF values are compared at a $150{ }^{\circ} \mathrm{C}$ reaction temperature, where conversion throughout the reactor becomes low so that initial reaction rate values can be taken. A significant increase in TOF can be observed with the reduction temperature, the higher proportion of $\mathrm{Pt}^{0}$ then compensating the activity loss due to the dispersion downturn. This effect is clearly observed in Figure 4, which shows the TOF, metal dispersion and $\mathrm{Pt}^{0} / \mathrm{Pt}^{\mathrm{n}+}$ ratio values of $\mathrm{Pt} / \mathrm{C}$ reduced at different temperatures.

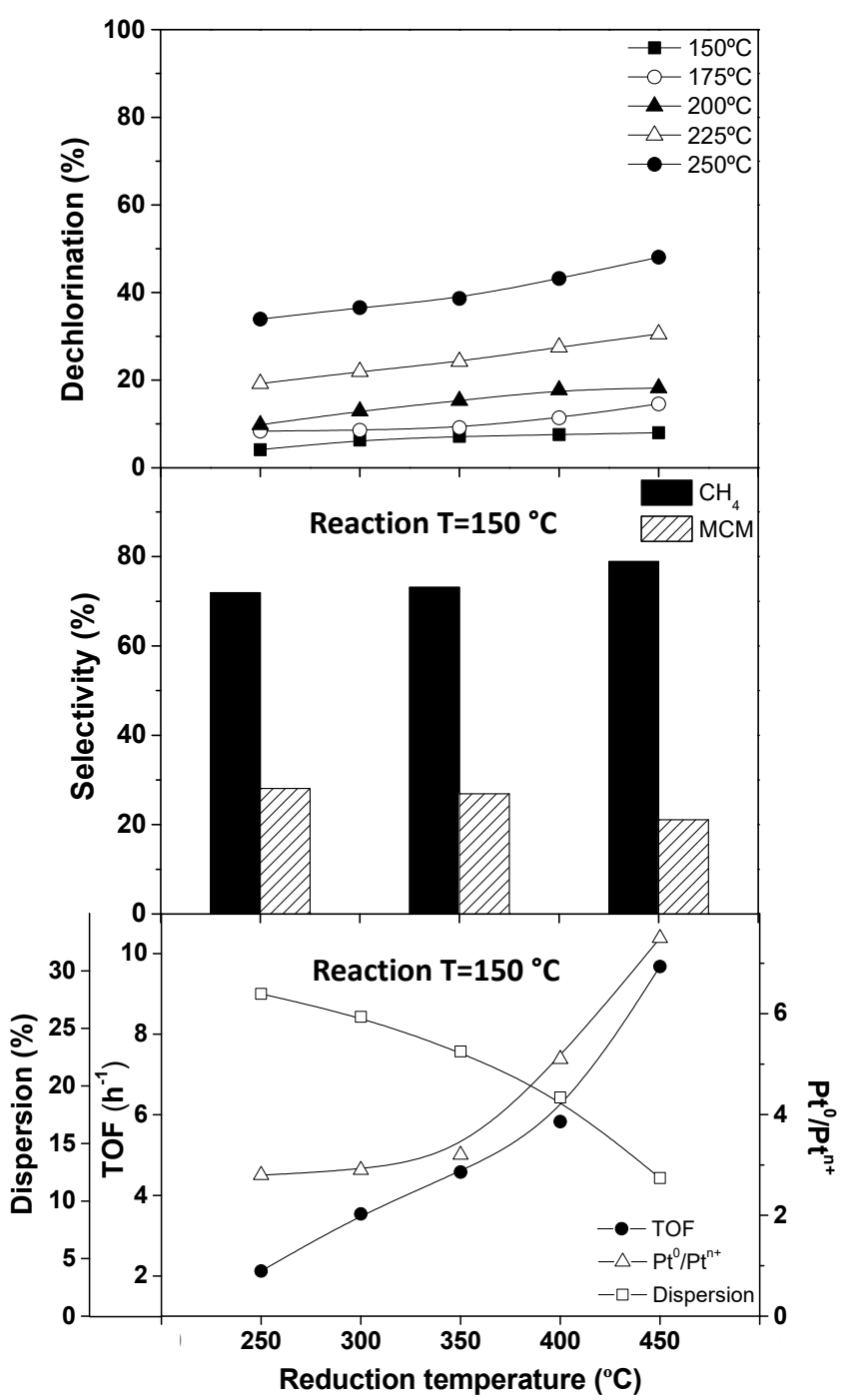

Figure 4. Results on the HDC of DCM within $150-250{ }^{\circ} \mathrm{C}$ reaction temperatures, at $0.6 \mathrm{~kg}$ cat $\cdot \mathrm{h} \cdot \mathrm{mol}^{-1}$ space-time, with the $\mathrm{Pt} / \mathrm{C}$ catalyst reduced at different temperatures.

As in previous works with platinum catalysts [14,16,19], the HDC of DCM with Pt/C only yielded methane (selectivity $>85 \%$ ) and methyl chloride (MCM) (see also Table S1 of supplementary material), independently of the reduction temperature used, due to the high zero-valent proportion of platinum. 
No significant variations of selectivity with the reduction temperature were found other than some slight increase towards methane, in accordance with the higher contribution of the $\mathrm{Pt}^{0}$ species in the dissociation of hydrogen during HDC.

Figure 5 shows the results with the $\mathrm{Pd} / \mathrm{C}$ catalyst. Substantially different trends are observed with respect to $\mathrm{Pt} / \mathrm{C}$. As can be seen, in contrast with $\mathrm{Pt} / \mathrm{C}$, overall dechlorination decreased dramatically at an increasing reduction temperature, with the effect being more pronounced at higher reaction temperatures. This can be attributed to the combination of two negative effects (see Table 2): (i) the decrease of the concentration of electro-deficient species, which are known to be the most active species in the HDC of DCM with palladium catalysts [12,19,38], and (ii) the decrease of palladium dispersion. Among the catalysts tested in this study, $\mathrm{Pd} / \mathrm{C}$ has been proven to be the most prone to sintering. Then, raising the reduction temperature of $\mathrm{Pd} / \mathrm{C}$ results in an important loss of accessible metallic surface, and the subsequent loss of activity observed. This results in a decrease in DCM conversion (Table S2 in Supplementary Material). In previous studies, it was stablished the optimum $\mathrm{Pd}^{0} / \mathrm{Pd}^{\mathrm{n}+}$ ratio around 1 for HDC reactions with Pd/C catalysts [19,36]. This is the value found in this study for the catalyst reduced at the lowest temperature. Despite the important loss of metal dispersion, no change in TOF is detected at reduction temperatures higher than $400{ }^{\circ} \mathrm{C}$, where $\mathrm{Pd}^{0} / \mathrm{Pd}^{\mathrm{n}+}$ ratio also remains constant.

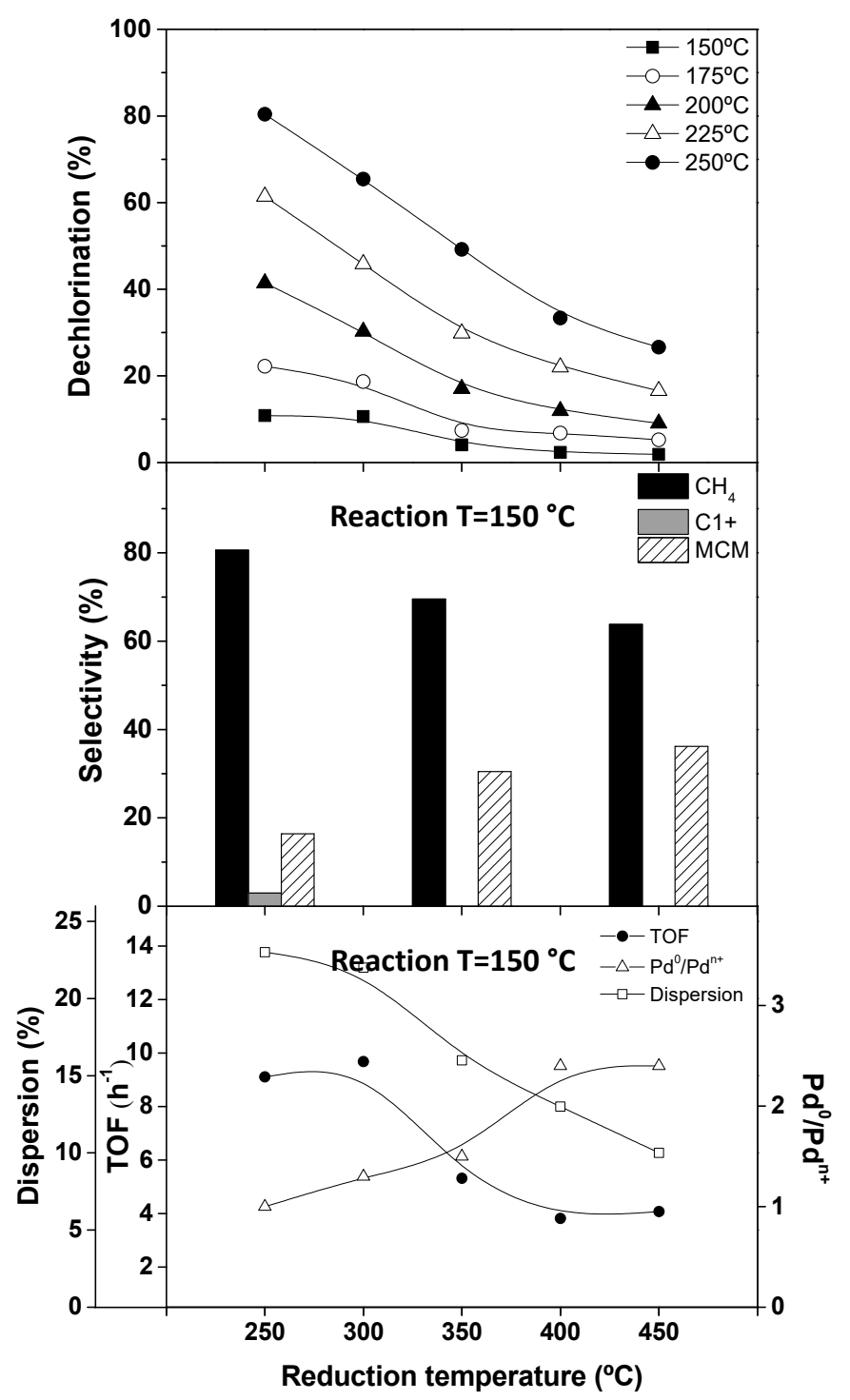

Figure 5. Results on the HDC of DCM within $150-250{ }^{\circ} \mathrm{C}$ reaction temperatures, at $0.6 \mathrm{~kg}$ cat $\cdot \mathrm{h} \cdot \mathrm{mol}^{-1}$ space-time, with the $\mathrm{Pd} / \mathrm{C}$ catalyst reduced at different temperatures. 
With Pd/C, the HDC of DCM yielded mainly methane, ethane and MCM. At the highest reaction temperatures, small amounts of propane were also formed (Table S2 of supplementary material). The catalyst reduced at the lowest temperature yielded small amounts of hydrocarbons higher than methane $(\mathrm{C} 1+)$, as can be observed in Figure 5. According to previous studies, this is favored by a higher electro-deficient to zero-valent palladium proportion $[14,19]$, due to the particular ability of electro-deficient $\mathrm{Pd}$ to dissociate $\mathrm{H}_{2}$. This was evidenced by molecular simulation studies [46], where the preferred adsorption of hydrogen in electro-deficient $\mathrm{Pd}^{\mathrm{n}+}$ species was reported when studying DCM and $\mathrm{H}_{2}$ interactions with Pd clusters by DFT. This would explain the decrease in methane selectivity. Hence, the concentration of MCM increases, it negatively affected the dechlorination obtained.

The results obtained with Rh/C are depicted in Figure 6. No significant effects of the reduction temperature can be pointed out, consistently with the almost unaltered characteristics given in Table 2 . This catalyst yielded by far the best performance in terms of dechlorination, being almost complete at a $250{ }^{\circ} \mathrm{C}$ reaction temperature. The selectivity towards hydrocarbons higher than methane $(\mathrm{C} 1+)$ was much higher than the obtained with the other two catalysts. Ethane was the most abundant among those hydrocarbons, but propane and even some smaller amounts of butane were also formed (see Table S3 of supplementary material).

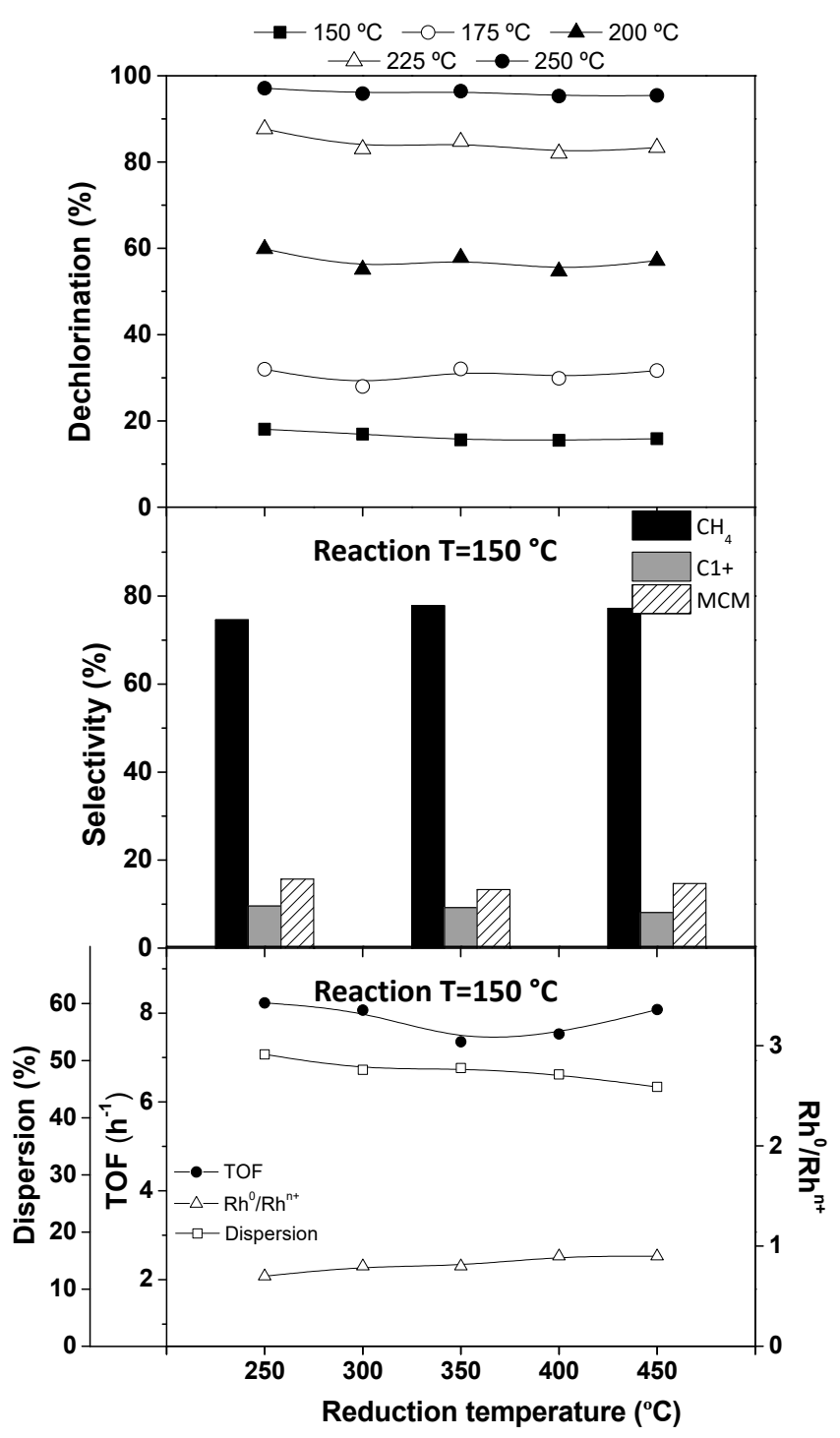

Figure 6. Results on the HDC of DCM within $150-250{ }^{\circ} \mathrm{C}$ reaction temperatures, at $0.6 \mathrm{~kg}$ cat $\cdot \mathrm{h} \cdot \mathrm{mol}^{-1}$ space-time, with the $\mathrm{Rh} / \mathrm{C}$ catalyst reduced at different temperatures. 


\section{Materials and Methods}

\subsection{Catalysts Preparation}

The catalysts were synthesized by incipient wetness impregnation. A commercial activated carbon (Erkimia S.A., $\mathrm{S}_{\mathrm{BET}}=1200 \mathrm{~m}^{2} \mathrm{~g}^{-1}$, pH slurry $=6.4$ [42]), was impregnated with aqueous solutions of $\mathrm{H}_{2} \mathrm{PtCl}_{6}, \mathrm{PdCl}_{2}$, and $\mathrm{RhCl}_{3}$ (all supplied by Sigma-Aldrich, Madrid, Spain) to get $1 \mathrm{wt}$ \% active phase nominal concentration. After $12 \mathrm{~h}$ at room temperature, the catalysts were dried at $100{ }^{\circ} \mathrm{C}\left(20{ }^{\circ} \mathrm{C} \mathrm{h}-1\right)$, for $2 \mathrm{~h}$. They were named $\mathrm{Pt} / \mathrm{C}, \mathrm{Pd} / \mathrm{C}$, and $\mathrm{Rh} / \mathrm{C}$.

The catalysts were activated by heating $\left(10^{\circ} \mathrm{C} \mathrm{min}^{-1}\right)$ up to the desired temperature (reduction temperatures between $250{ }^{\circ} \mathrm{C}$ and $450{ }^{\circ} \mathrm{C}$ were tested) under $\mathrm{H}_{2}$ flow $\left(50 \mathrm{Ncm}^{3} \mathrm{~min}^{-1}\right.$, delivered by Praxair, Madrid, Spain, minimum purity of $99.999 \%$ ) for $2 \mathrm{~h}$.

\subsection{Catalysts Characterization}

$\mathrm{N}_{2}$ adsorption-desorption analysis were performed at $-196^{\circ} \mathrm{C}$ (Tristar II 3020, Micromeritics, Alcobendas, Spain) to characterized the porous texture of the catalysts. Previously, the samples were outgassed for $12 \mathrm{~h}$ at $150{ }^{\circ} \mathrm{C}$ (VacPrep 061, Micromeritics, Alcobendas, Spain). The BET equation was used to determine the surface areas.

The metal content (platinum, palladium and rhodium) of the synthesized catalysts was determined by ICP-MS with an Elan 6000 (Perkin-Elmer, Tres Cantos, Spain). Previously, the samples were dissolved in $\mathrm{HNO}_{3}: 3 \mathrm{HCl}$, and digested for $15 \mathrm{~min}$ at $180{ }^{\circ} \mathrm{C}$ in a microwave oven (Milestone Ethos Plus, Madrid, Spain).

Metal dispersion was determined by CO chemisorption (PulseChemiSorb 2705, Micromeritics, Alcobendas, Spain), assuming a stoichiometry of 1:1 for the adsorption of the CO molecules on the metallic atoms [43-45,47].

The elements present on the surface of the catalysts and their concentrations were determined by XPS (5700C Multitechnique System, Physical Electronics, Madrid, Spain), scanning up to a binding energy (BE) of $1200 \mathrm{eV}$, using $\mathrm{Mg}-\mathrm{K} \alpha$ radiation $(1253.6 \mathrm{eV})$. In order to rectify the shift in BE produced by sample charging, the $\mathrm{C} 1 \mathrm{~s}$ peak $(284.6 \mathrm{eV})$ was used as an internal standard. To estimate the chemical state of $\mathrm{Pt}, \mathrm{Pd}, \mathrm{Rh}$ and $\mathrm{O}$ on the catalyst surface, the $\mathrm{BE}$ of the $\mathrm{O} 1 \mathrm{~s}, \mathrm{Pt} 4 \mathrm{f}_{7 / 2}, \mathrm{Pd} 3 \mathrm{~d}_{5 / 2}$, and $\mathrm{Rh} 3 \mathrm{~d}_{5 / 2}$ core levels and the full width at half maximum data were used, deconvoluting the peaks by mixed Gaussian-Lorentzian functions (least-squares method) [48].

TEM was carried by a JEOL JEM-3000F microscope $(300 \mathrm{kV}$, point resolution of $0.17 \mathrm{~nm}$, Madrid, Spain), equipped with a high-angle annular dark field (HAADF) detector and a 1k x 1k ULTRASCAN multi sweep CCD camera. Chemical analysis was done by Energy Disperse X-ray Spectroscopy (XEDS) using an Oxford Instruments INCA Energy TEM 250 (Madrid, Spain). Previously, the catalysts were dispersed in ethanol and placed onto holey carbon-coated $\mathrm{Cu}$ grids (Aname, Madrid, Spain).

The XRD patterns of the catalysts at different reduction temperatures $\left(250,350\right.$ and $\left.450{ }^{\circ} \mathrm{C}\right)$ were driven in a X'Pert PRO Panalytical Diffractometer (Madrid, Spain), scanning up to a $2 \theta$ of $100^{\circ}$ (step size of $0.020^{\circ}, 5$ s collection time), using $\mathrm{CuK} \alpha$ monochromatic radiation $(\mathrm{k}=0.15406 \mathrm{~nm})$ and a $\mathrm{Ge}$ mono filter.

\subsection{Catalytic Activity Experiments}

The HDC experiments were performed in a Microactivity Pro (Tres Cantos, Spain) reaction system described previously [49], consisting of a quartz fixed bed micro-reactor operating under continuous flow. In order to analyze the reaction products, the system was coupled to a gas-chromatograph with a flame ionization detector (FID).

The experiments were conducted at atmospheric pressure. The total flow rate $\left(\mathrm{DCM}+\mathrm{H}_{2}+\mathrm{N}_{2}\right)$ used was $100 \mathrm{Ncm}^{3} \mathrm{~min}^{-1}$. Finally, a DCM inlet concentration of $1000 \mathrm{ppmv}$ and a $\mathrm{H}_{2} / \mathrm{DCM}$ molar ratio of 100 were employed. Reaction temperatures of $150-250{ }^{\circ} \mathrm{C}$ were evaluated. All the experiments were performed by triplicate, using a space-time $(\tau)$ of $0.6 \mathrm{~kg} \mathrm{~h} \mathrm{~mol}^{-1}$. 
The catalysts were evaluated in terms of overall dechlorination, metallic intrinsic activity or TOF, DCM conversion and selectivity to the different reaction products.

\section{Conclusions}

From the results obtained it follows that $\mathrm{Pd}$ is more prone than $\mathrm{Pt}$ and $\mathrm{Rh}$ to sintering and, therefore, increasing the reduction temperature provokes a dramatic decrease of activity, leading to poor dechlorination of DCM even at the highest reaction temperature investigated $\left(250^{\circ} \mathrm{C}\right)$. Sintering was of lower significance in the case of $\mathrm{Pt}$ and almost did not occur with $\mathrm{Rh}$. On the other hand, by increasing the reduction temperature, the ratio of zero-valent to electro-deficient species increased significantly in the $\mathrm{Pd} / \mathrm{C}$ catalyst and to a lower extent in $\mathrm{Pt} / \mathrm{C}$, while remaining basically unchanged in $\mathrm{Rh} / \mathrm{C}$. This led to a significant increase of TOF in $\mathrm{Pt} / \mathrm{C}$ since in this catalyst $\mathrm{Pt}^{0}$ is the main active specie for HDC, thus compensating for the loss of dispersion at a higher reduction temperature. In contrast, the decrease of $\mathrm{Pd}^{\mathrm{n}+}$ (main active center for $\mathrm{Pd} / \mathrm{C}$ ) together with the significant decrease of dispersion caused a remarkable drop of TOF and overall dechlorination. Meanwhile, no significant changes occurred in the case of $\mathrm{Rh} / \mathrm{C}$ consistently with its stable properties upon reduction at different temperatures. This higher stability of $\mathrm{Rh} / \mathrm{C}$ can be ascribed to a higher concentration of surface oxygen groups, particularly of basic character, which favors the metal-support interaction, avoiding metal sintering and protecting the electro-deficient species.

It can be concluded that $250{ }^{\circ} \mathrm{C}$ is the optimum reduction temperature for $\mathrm{Pd} / \mathrm{C}$, while for $\mathrm{Pt} / \mathrm{C}$ better results were obtained after reduction at $450{ }^{\circ} \mathrm{C}$, and no significant effects were observed in the case of $\mathrm{Rh} / \mathrm{C}$.

Supplementary Materials: The following are available online at http:/ / www.mdpi.com/2073-4344/8/12/664/s1, Figure S1. XPS deconvolution of Pt $4 \mathrm{f}$ on Pt/C catalyst reduced at: $250{ }^{\circ} \mathrm{C}(\mathrm{A}), 30{ }^{\circ} \mathrm{C}(\mathrm{B}), 350^{\circ} \mathrm{C}(\mathrm{C}), 400{ }^{\circ} \mathrm{C}$ (D) and $450{ }^{\circ} \mathrm{C}(\mathrm{E})$; Figure S2. XPS deconvolution of Pd $3 \mathrm{~d}$ on Pd/C catalyst reduced at: $250{ }^{\circ} \mathrm{C}(\mathrm{A}), 300^{\circ} \mathrm{C}(\mathrm{B})$, $350{ }^{\circ} \mathrm{C}(\mathrm{C}), 400{ }^{\circ} \mathrm{C}$ (D) and $450{ }^{\circ} \mathrm{C}$ (E); Figure S3. XPS deconvolution of Rh $3 \mathrm{~d}$ on $\mathrm{Rh} / \mathrm{C}$ catalyst reduced at: $250{ }^{\circ} \mathrm{C}$ (A), $300^{\circ} \mathrm{C}(\mathrm{B}), 350{ }^{\circ} \mathrm{C}(\mathrm{C}), 400{ }^{\circ} \mathrm{C}$ (D) and $450{ }^{\circ} \mathrm{C}$ (E); Figure S4. XPS spectra of O 1s on Pt/C catalyst reduced at different temperatures; Figure S5. XPS spectra of $\mathrm{O} 1 \mathrm{~s}$ on $\mathrm{Pd} / \mathrm{C}$ catalyst reduced at different temperatures; Figure S6. XPS spectra of $\mathrm{O}$ 1s on $\mathrm{Rh} / \mathrm{C}$ catalyst reduced at different temperatures; Table S1. Initial conversions and selectivities to reaction products in the HDC of DCM with $\mathrm{Pt} / \mathrm{C}$ catalyst reduced at different temperatures; Table S2. Initial conversions and selectivities to reaction products in the HDC of DCM with $\mathrm{Pd} / \mathrm{C}$ catalyst reduced at different temperatures; Table S3. Initial conversions and selectivities to reaction products in the HDC of DCM with $\mathrm{Rh} / \mathrm{C}$ catalyst reduced at different temperatures.

Author Contributions: Conceptualization, J.J.-R. and L.M.G.-S.; investigation, A.A.-B. and M.M.-M.; methodology, A.A.-B., M.M.-M. and M.A.Á.-M.; data analysis, A.A.-B., M.M.-M, M.A.A.-M, J.J.-R. and L.M.G.-S.; supervision, M.A.Á.-M., J.J.-R. and L.M.G.-S.; writing—original draft preparation, A.A.-B. and M.M.-M.; writing—review and editing, M.A.Á.-M., J.J.-R. and L.M.G.-S.

Funding: The authors gratefully acknowledge financial support from the Spanish Ministerio de Economía y Competitividad (MINECO) through the projects CTM 2014-53008 and CTM2017-85498-R. A. Arevalo Bastante acknowledges MINECO for her research grant. M. Martín Martínez acknowledges the postdoc grant 2017-T2/AMB-5668 from Comunidad de Madrid, Programme "Atracción de talento investigador".

Conflicts of Interest: The authors declare no conflict of interest.

\section{References}

1. Hayes, W.J., Jr.; Laws, E.R., Jr. Handbook of Pesticide Toxicology, Vol. 1: General Principles; Academic Press: San Diego, CA, USA, 1991.

2. Lewis, N.M.; Gatchett, A.M. U.S. Environmental Protection Agency's SITE Emerging Technology Program: 1991 Update. J. Air Waste Manag. Assoc. 1991, 41, 1645-1653. [CrossRef]

3. Ciccioli, P. Chemistry and Analysis of Volatile Organic Compounds in the Environment; Bloemen, H.J.T., Burn, J., Eds.; Springer: Glasgow, UK, 1993; pp. 92-174.

4. Dobrzynska, E.; Posniak, M.; Szewczynska, M.; Buszewski, B. Chlorinated Volatile Organic Compounds-Old, However, Actual Analytical and Toxicological Problem. Crit. Rev. Anal. Chem. 2010, 40, 41-57. [CrossRef]

5. Noelke, C.J.; Rase, H.F. Improved Hydrodechlorination Catalysis-Chloroform Over Platinum-Alumina with Special Treatments. Ind. Eng. Chem. Prod. Res. Dev. 1979, 18, 325-328. [CrossRef] 
6. Ordoñez, S.; Sastre, H.; Diez, F.V. Hydrodechlorination of aliphatic organochlorinated compounds over commercial hydrogenation catalysts. Appl. Catal. B Environ. 2000, 25, 49-58. [CrossRef]

7. Urbano, F.J.; Marinas, J.M. Hydrogenolysis of Organohalogen Compounds Over Palladium Supported Catalysts. J. Mol. Catal. A Chem. 2001, 173, 329-345. [CrossRef]

8. Elola, A.; Diaz, E.; Ordoñez, S. A New Procedure for the Treatment of Organochlorinated Off-Gases Combining Adsorption and Catalytic Hydrodechlorination. Environ. Sci. Technol. 2009, 43, 1999-2004. [CrossRef] [PubMed]

9. Prati, L.; Rossi, M. Reductive Catalytic Dehalogenation of Light Chlorocarbons. Appl. Catal. B Environ. 1999, 23, 135-142. [CrossRef]

10. Gomez-Sainero, L.M.; Cortes, A.; Seoane, X.L.; Arcoya, A. Hydrodechlorination of Carbon Tetrachloride to Chloroform in the Liquid Phase with Metal-Supported Catalysts. Effect of the Catalyst Components. Ind. Eng. Chem. Res. 2000, 39, 2849-2854. [CrossRef]

11. Gonzalez, C.A.; Bartoszek, M.; Martin, A.; de Correa, C.M. Hydrodechlorination of Light Organochlorinated Compounds and Their Mixtures over Pd/ $\mathrm{TiO}_{2}$-Washcoated Minimonoliths. Ind. Eng. Chem. Res. 2009, 48, 2826-2835. [CrossRef]

12. Alvarez-Montero, M.A.; Gomez-Sainero, L.M.; Martin-Martinez, M.; Heras, F.; Rodriguez, J.J. Hydrodechlorination of Chloromethanes with Pd on Activated Carbon Catalysts for the Treatment of Residual Gas Streams. Appl. Catal. B Environ. 2010, 96, 148-156. [CrossRef]

13. Keane, M.A. Supported Transition Metal Catalysts for Hydrodechlorination Reactions. ChemCatChem 2011, 3, 800-821. [CrossRef]

14. Alvarez-Montero, M.A.; Gomez-Sainero, L.M.; Juan-Juan, J.; Linares-Solano, A.; Rodriguez, J.J. Gas-Phase Hydrodechlorination of Dichloromethane With Activated Carbon-Supported Metallic Catalysts. Chem. Eng. J. 2010, 162, 599-608. [CrossRef]

15. Calvo, L.; Gilarranz, M.A.; Casas, J.A.; Mohedano, A.F.; Rodriguez, J.J. Hydrodechlorination of Diuron in Aqueous Solution with Pd, Cu and Ni on Activated Carbon Catalysts. Chem. Eng. J. 2010, 163, 212-218. [CrossRef]

16. Alvarez-Montero, M.A.; Gomez-Sainero, L.M.; Mayoral, A.; Diaz, I.; Baker, R.T.; Rodriguez, J.J. Hydrodechlorination of Chloromethanes with a Highly Stable Pt on Activated Carbon Catalyst. J. Catal. 2011, 279, 389-396. [CrossRef]

17. Shao, Y.; Xu, Z.; Wan, H.; Wan, Y.; Chen, H.; Zheng, S.; Zhu, D. Enhanced Liquid Phase Catalytic Hydrodechlorination of 2,4-Dichlorophenol Over Mesoporous Carbon Supported Pd Catalysts. Catal. Commun. 2011, 12, 1405-1409. [CrossRef]

18. Ha, J.; Kim, D.; Kim, J.; Kim, S.K.; Ahn, B.S.; Kang, J.W. Supercritical-Phase-Assisted Highly Selective and Active Catalytic Hydrodechlorination of the Ozone-Depleting Refrigerant $\mathrm{CHClF}_{2}$. Chem. Eng. J. 2012, 213, 346-355. [CrossRef]

19. Martin-Martinez, M.; Gomez-Sainero, L.M.; Alvarez-Montero, M.A.; Bedia, J.; Rodriguez, J.J. Comparison of Different Precious Metals in Activated Carbon-Supported Catalysts for the Gas-Phase Hydrodechlorination of Chloromethanes. Appl. Catal. B Environ. 2013, 132, 256-265. [CrossRef]

20. Cárdenas-Lizana, F.; Hao, Y.; Crespo-Quesada, M.; Yuranov, I.; Wang, X.; Keane, M.A.; Kiwi-Minsker, L. Selective Gas Phase Hydrogenation of p-Chloronitrobenzene over Pd Catalysts: Role of the Support. ACS Catal. 2013, 3, 1386-1396. [CrossRef]

21. Díaz, E.; McCall, A.; Faba, L.; Sastre, H.; Ordóñez, S. Trichloroethylene Hydrodechlorination in Water Using Formic Acid as Hydrogen Source: Selection of Catalyst and Operation Conditions. Environ. Prog. Sustain. Energy 2013, 32, 1217-1222. [CrossRef]

22. Gregori, M.; Fornasari, G.; Marchionni, G.; Tortelli, V.; Millefanti, S.; Albonetti, S. Hydrogen-Assisted Dechlorination of $\mathrm{CF}_{3} \mathrm{OCFCl}-\mathrm{CF}_{2} \mathrm{Cl}$ to $\mathrm{CF}_{3} \mathrm{OCF}=\mathrm{CF}_{2}$ Over Different Metal-Supported Catalysts. Appl. Catal. A Gen. 2014, 470, 123-131. [CrossRef]

23. Arevalo-Bastante, A.; Álvarez-Montero, M.A.; Bedia, J.; Gómez-Sainero, L.M.; Rodriguez, J.J. Gas-Phase Hydrodechlorination of Mixtures of Chloromethanes with Activated Carbon-Supported Platinum Catalyst. Appl. Catal. B Environ. 2015, 179, 551-557. [CrossRef]

24. Srikanth, C.S.; Kumar, V.P.; Viswanadham, B.; Chary, K.V.R. Hydrodechlorination of 1,2,4-Trichlorbenzene Over Supported Ruthenium Catalysts on Various Supports. Catal. Commun. 2011, 13, 69-72. [CrossRef] 
25. Diaz, E.; Mohedano, A.F.; Casas, J.A.; Calvo, L.; Gilarranz, M.A.; Rodriguez, J.J. Comparison of Activated Carbon-Supported Pd and Rh Catalysts for Aqueous-Phase Hydrodechlorination. Appl. Catal. B Environ. 2011, 106, 469-475. [CrossRef]

26. Baeza, J.A.; Calvo, L.; Gilarranz, M.A.; Mohedano, A.F.; Casas, J.A.; Rodriguez, J.J. Catalytic Behavior of Size-Controlled Palladium Nanoparticles in the Hydrodechlorination of 4-Chlorophenol in Aqueous Phase. J. Catal. 2012, 293, 85-93. [CrossRef]

27. Ren, Y.; Fan, G.; Wang, C. Aqueous Hydrodechlorination of 4-Chlorophenol Over an Rh/Reduced Graphene Oxide Synthesized by a Facile One-Pot Solvothermal Process Under Mild Conditions. J. Hazard. Mater. 2014, 274, 32-40. [CrossRef] [PubMed]

28. Baeza, J.A.; Calvo, L.; Gilarranz, M.A.; Rodriguez, J.J. Effect of Size and Oxidation State of Size-Controlled Rhodium Nanoparticles on the Aqueous-Phase Hydrodechlorination of 4-Chlorophenol. Chem. Eng. J. 2014, 240, 271-280. [CrossRef]

29. Baeza, J.A.; Calvo, L.; Rodriguez, J.J.; Gilarranz, M.A. Catalysts Based on Large Size-Controlled Pd Nanoparticles for Aqueous-Phase Hydrodechlorination. Chem. Eng. J. 2016, 294, 40-48. [CrossRef]

30. Dantas Ramos, A.L.; Alves, P.D.S.; Aranda, D.A.G.; Schmal, M. Characterization of Carbon Supported Palladium Catalysts: Inference of Electronic and Particle Size Effects Using Reaction Probes. Appl. Catal. A Gen. 2004, 277, 71-81. [CrossRef]

31. Bedia, J.; Arevalo-Bastante, A.; Grau, J.M.; Dosso, L.A.; Rodriguez, J.J.; Mayoral, A.; Diaz, I.; Gómez-Sainero, L.M. Effect of the Pt-Pd Molar Ratio in Bimetallic Catalysts Supported on Sulfated Zirconia on the Gas-Phase Hydrodechlorination of Chloromethanes. J. Catal. 2017, 352, 562-571. [CrossRef]

32. Malinowski, A.; Lomot, D.; Karpinski, Z. Hydrodechlorination of $\mathrm{CH}_{2} \mathrm{Cl}_{2}$ over Pd/gamma- $\mathrm{Al}_{2} \mathrm{O}_{3}$. Correlation with the Hydrodechlorination of $\mathrm{CCl}_{2} \mathrm{~F}_{2}$ (CFC-12). Appl. Catal. B Environ. 1998, 19, L79-L86. [CrossRef]

33. Sánchez, C.A.G.; Patiño, C.O.M.; de Correa, C.M. Catalytic Hydrodechlorination of Dichloromethane in the Presence of Traces of Chloroform and Tetrachloroethylene. Catal. Today 2008, 133-135, 520-525. [CrossRef]

34. Cobo, M.; Becerra, J.; Castelblanco, M.; Cifuentes, B.; Conesa, J.A. Catalytic Hydrodechlorination of Trichloroethylene in a Novel NaOH/2-Propanol/Methanol/Water System on Ceria-Supported Pd and Rh Catalysts. J. Environ. Manag. 2015, 158, 1-10. [CrossRef] [PubMed]

35. Álvarez-Montero, M.A.; Martin-Martinez, M.; Gómez-Sainero, L.M.; Arevalo-Bastante, A.; Bedia, J.; Rodriguez, J.J. Kinetic Study of the Hydrodechlorination of Chloromethanes with Activated-Carbon-Supported Metallic Catalysts. Ind. Eng. Chem. Res. 2015, 54, 2023-2029. [CrossRef]

36. Martin-Martinez, M.; Alvarez-Montero, M.A.; Gomez-Sainero, L.M.; Baker, R.T.; Palomar, J.; Omar, S.; Eser, S.; Rodriguez, J.J. Deactivation Behavior of Pd/C and Pt/C Catalysts in the Gas-Phase Hydrodechlorination of Chloromethanes: Structure-Reactivity Relationship. Appl. Catal. B Environ. 2015, 162, 532-543. [CrossRef]

37. Bedia, J.; Gomez-Sainero, L.M.; Grau, J.M.; Busto, M.; Martin-Martinez, M.; Rodriguez, J.J. Hydrodechlorination of Dichloromethane With Mono- and Bimetallic Pd-Pt on Sulfated and Tungstated Zirconia Catalysts. J. Catal. 2012, 294, 207-215. [CrossRef]

38. Martin-Martinez, M.; Gómez-Sainero, L.M.; Bedia, J.; Arevalo-Bastante, A.; Rodriguez, J.J. Enhanced Activity of Carbon-Supported Pd-Pt Catalysts in the Hydrodechlorination of Dichloromethane. Appl. Catal. B Environ. 2016, 184, 55-63. [CrossRef]

39. Lesiak, B.; Jiricek, P.; Bieloshapka, I. Chemical and Structural Properties of Pd Nanoparticle-Decorated Graphene-Electron Spectroscopic Methods and QUASES. Appl. Surf. Sci. 2017, 404, 300-309. [CrossRef]

40. Castillejos, E.; García-Minguillán, A.M.; Bachiller-Baeza, B.; Rodríguez-Ramos, I.; Guerrero-Ruiz, A. When the Nature of Surface Functionalities on Modified Carbon Dominates the Dispersion of Palladium Hydrogenation Catalysts. Catal. Today 2018, 301, 248-257. [CrossRef]

41. An, N.; Zhang, M.; Zhang, Z.; Dai, Y.; Shen, Y.; Tang, C.; Yuan, X.; Zhou, W. High-Performance Palladium Catalysts for the Hydrogenation Toward Dibenzylbiotinmethylester: Effect of Carbon Support Functionalization. J. Colloid Interface Sci. 2018, 510, 181-189. [CrossRef] [PubMed]

42. Gomez-Sainero, L.M.; Seoane, X.L.; Fierro, J.L.G.; Arcoya, A. Liquid-Phase Hydrodechlorination of $\mathrm{CCl}_{4}$ to $\mathrm{CHCl}_{3}$ on Pd/Carbon Catalysts: Nature and Role of Pd Active Species. J. Catal. 2002, 209, 279-288. [CrossRef]

43. Ali, S.H.; Goodwin, J.G. SSITKA Investigation of Palladium Precursor and Support Effects on CO Hydrogenation over Supported Pd Catalysts. J. Catal. 1998, 176, 3-13. [CrossRef] 
44. Mahata, N.; Vishwanathan, V. Gas phase Hydrogenation of Phenol Over Supported Palladium Catalysts. Catal. Today 1999, 49, 65-69. [CrossRef]

45. Kulkarni, P.P.; Deshmukh, S.S.; Kovalchuk, V.I.; d'Itri, J.L. Hydrodechlorination of Dichlorodifluoromethane on Carbon-Supported Group VIII Noble Metal Catalysts. Catal. Lett. 1999, 61, 161-166. [CrossRef]

46. Omar, S.; Palomar, J.; Gomez-Sainero, L.M.; Alvarez-Montero, M.A.; Martin-Martinez, M.; Rodriguez, J.J. Density Functional Theory Analysis of Dichloromethane and Hydrogen Interaction with Pd Clusters: First Step to Simulate Catalytic Hydrodechlorination. J. Phys. Chem. C 2011, 115, 14180-14192. [CrossRef]

47. Gasser-Ramirez, J.L.; Dunn, B.C.; Ramirez, D.W.; Fillerup, E.P.; Turpin, G.C.; Shi, Y.; Ernst, R.D.; Pugmire, R.J.; Eyring, E.M.; Pettigrew, K.A.; et al. A Simple Synthesis of Catalytically Active, High Surface Area Ceria Aerogels. J. Non-Cryst. Solids 2008, 354, 5509-5514. [CrossRef]

48. Wagner, C.D.; Davis, L.E.; Zeller, M.V.; Taylor, J.A.; Raymond, R.H.; Gale, L.H. Empirical Atomic Sensitivity Factors for Quantitative Analysis by Electron Spectroscopy for Chemical Analysis. Surf. Interface Anal. 1981, 3, 211-225. [CrossRef]

49. de Pedro, Z.M.; Gómez-Sainero, L.M.; González-Serrano, E.; Rodriguez, J.J. Gas-Phase Hydrodechlorination of Dichloromethane at Low Concentrations with Palladium/Carbon Catalysts. Ind. Eng. Chem. Res. 2006, 45, 7760-7766. [CrossRef]

(C) 2018 by the authors. Licensee MDPI, Basel, Switzerland. This article is an open access article distributed under the terms and conditions of the Creative Commons Attribution (CC BY) license (http:/ / creativecommons.org/licenses/by/4.0/). 